Article

\title{
Framing Islam/Creating Fear: An Analysis of U.S. Media Coverage of Terrorism from 2011-2016
}

\author{
Kimberly A. Powell \\ Communication Studies Department, Luther College, Decorah, IA 52101, USA; kimpowell@luther.edu; \\ Tel.: +1-563-387-1362
}

Received: 17 July 2018; Accepted: 26 August 2018; Published: 28 August 2018

\begin{abstract}
Powell's 2011 study of media coverage of 11 post-9/11 terrorist events argued that a thematic framing exists which results in a model of media coverage of terrorism that is different for acts of terror committed by Muslims than by non-Muslims. This pattern connects terrorism to Islam, thus creating a fear of the "other" and aids terrorists in achieving their goal of creating a climate of fear. This study examines the 11 terrorist events since the last study, between 2011 and 2016, to determine if any changes in media coverage of terrorism have occurred in a climate of increased awareness of Islamophobia.
\end{abstract}

Keywords: media framing; terrorism; Orientalism; news media; Islam; Muslim; Islamophobia

\section{Introduction}

In 2011, a study examining 11 terrorist events in the U.S. since 9/11 argued that media coverage of terrorist events intensifies fear of Islam and Muslims by covering events committed by Muslims as part of a larger conspiracy of Islam on the U.S., while explaining terrorist events committed by non-Muslim U.S. citizens as isolated individual acts of the mentally ill (Powell 2011). Powell argued that the coverage was largely influenced by and influenced the U.S. government war on terror (Reese and Lewis 2009; Powell 2011), sustaining media attention and creating an Us versus Them, or the U.S. versus Islam mentality (Powell and Abadi 2003).

In recent years, though the awareness of Islamophobia has grown, the climate of fear of Islam has persisted and even increased, resulting in efforts to halt immigration for those from Islamic countries. Thus, this parallel study examines the 11 terrorist attacks occurring from 2011-2016 in the U.S. to determine if the pattern of media coverage persists, or if it has shifted in a changing political climate more aware of Islamophobia.

\section{Terrorism and Media}

Terrorism is defined in a variety of ways; however, after studying many definitions, A.P. Schmid, a UN advisor, found 22 similarities, resulting in this definition:

Terrorism is an anxiety inspiring method of repeated violent action, employed by (semi-) clandestine individual, group or state actors, for idiosyncratic, criminal or political reasons, whereby-in contrast to assassination - the direct targets of violence are not the main targets. The immediate human victims of violence are generally chosen randomly (targets of opportunity) or selectively (representative of symbolic targets) from a target population, and serve as message generators. Threat- and violence-based communication processes between terrorist (organization), (imperiled) victims, and main targets are used to manipulate the main target (audience(s)), turning it into a target of terror, a target of demands, or a target of attention depending on whether intimidation, coercion, or propaganda is primarily sought. (Schmid 1983, p. 70) 
This definition highlights the intent of terrorism being to communicate a message and fear, and that those killed and injured are not intentional targets, but means to delivering a message to an organization or government. This definition of terrorism excludes school shooters as the shooter is typically acting out in rage versus attempting to send a message to higher powers. However, it does not necessarily exclude hate crimes, for hate crimes are carried out by those delivering a message to a target population to create fear or terror.

After the Boston Marathon bombing, the definition of terrorism in the U.S. was reconsidered while a motive was investigated. President Obama was more cautious than previous administrations to define an act as terrorism:

Experts-and the dictionary-define terrorism as the use of violence and fear to pursue political goals .... President Barack Obama didn't use the word when he spoke hours after the attack. By Tuesday, he called it an "act of terror" any time bombs are used to target innocent civilians ... some history students at Kent Place School in New Jersey ... want more information before deciding what to call the Boston tragedy. (Associated Press 2013a)

Though Obama's hesitancy to label an act as terrorism can slow media framing of a terrorist act, the role of media in framing acts of violence as terrorism and attributing motives differently to Muslims versus non-Muslims plays a vital role in the creation of a climate of Islamophobia. Because media are drawn to cover terrorist acts, and terrorists know that they can create media focus on a "shocking and sensational" act (Tuman 2010, p. 196), the result is nonstop coverage after an event that creates a climate of fear. Media is the tool used by terrorists to convey their message. A pioneer of terrorism research Brian Jenkins argues that those committing terrorist acts who are Muslim are motivated more by "the desire to be part of a historic epic struggle" (Miller 2013), which is highlighted by media coverage. In recent years, rather than being from outside the U.S., the terrorist is most likely to be an American who is a "malleable youngish male, a loner, a bit of a loser" (Miller 2013). No longer are terrorists solely international, rather they tend to be U.S. citizens with an international connection who gain media attention for their act.

We know that media coverage of an event affects public perceptions (Jamieson and Waldman 2003) depending on how it is framed. Given the limited knowledge of Islam and Muslim countries, the U.S. public has consumed a media framed Islam from abroad as the major terrorism threat (Powell 2011). That fact that Western media participates in bias and creates stereotypes against religions and peoples (Brummett 1994; Chesebro and Bertelsen 1996; Markham and Maslog 1971; Semati 2010; Shahin 2015) against Islam is accepted in the academic world, and Said (1978) explains that since most do not separate Islam and Muslims, the actions of one Muslim are equated with all Muslims. So if one Muslim is a terrorist, we should fear all Muslims, setting up an Islam versus the West mentality, or as Huntington (1993) predicted, a Clash of Civilizations. Due to this Orientalist framing, Edward Said argues that the result is "a Western style for dominating, restructuring, and having authority over the Orient" (Said 1978, p. 3).

\section{Method}

The power of the mass media to organize and present information is powerful in distributing ideologies through framing (Gitlin 1980). Framing is the organization of information into news stories written for an audience that enables them to comprehend events, peoples, religions, etc. through a particular focus, lens, or frame (Goffman 1974; Ryan 1991; Shook 2000). Reporters and news outlets select which information to include in coverage and to what degree, which controls what the public knows and the lens or frame through which they view similar information. When a frame becomes established, it becomes, as Reese explains, "organizing principles that are socially shared and persistent over time, that work symbolically to meaningfully structure the social world" (Reese 2001, p. 9), making some aspects of reporter perceived reality or biases more salient than others (Entman 1993). When those salient elements become dominant, a frame is created that can impact other journalists who frame 
the situation identically, thus expanding the frame and making it dominant and the story seem one dimensional (Entman 1989; Entman and Rojecki 1993). As a result, a hegemonic ideology emerges which becomes the "common sense" (Gitlin 1980, p. 10) of the masses, resulting in identifying problems and moral judgments viewed through the frame (Entman 1993). For example, the media framing found in Powell's 2011 study portrayed international Muslims as terrorists part of a larger threat to the U.S., thus audiences were more likely to conclude that Muslims are terrorists.

U.S. media coverage of terrorism arguably goes past thematic event coverage, impacting and engaging political party positions and policy debate (Iyengar and Simon 1993). Similar frames can be used by media and politicians to argue for policies as they are accepted by the public (Norris et al. 2003). Due to the power of frames to impact policy, it is vital to identify and critique media frames.

\section{Framing Analysis}

This analysis of 11 terrorist events on U.S. soil from 2011-2016, asks if the media framing discovered in Powell's 2011 study persists in an age more aware of Islamophobia and its effects. Though there were more intercepted terrorist acts or acts when the perpetrator was not apprehended, the 11 events chosen for this study were completed, with the perpetrator caught, and some reported the event as terrorism (see Table 1).

Table 1. Terrorist events in the U.S. 2010-2016.

\begin{tabular}{|c|c|c|}
\hline Date & Who Committed the Act & Description of Event \\
\hline April 2013 & $\begin{array}{c}\text { Tamerian Tsarnaev \& Dzhokar } \\
\text { Tsarnaev }\end{array}$ & $\begin{array}{c}\text { Bombing at the Boston Marathon killed } 4 \text { and } \\
\text { injured over } 180\end{array}$ \\
\hline November 2013 & Paul Anthony Ciancia & $\begin{array}{l}\text { Shooting at LA International Airport. One } \\
\text { killed, } 6 \text { injured. }\end{array}$ \\
\hline April 2014 & Frazier Glenn Miller, Jr. & $\begin{array}{c}\text { Shooting at Overland Park Jewish Community } \\
\text { Center killed } 3\end{array}$ \\
\hline June 2014 & Jerad and Amanda Miller & Shooting in Las Vegas killed 3 \\
\hline November 2014 & Larry Steven McQuilliams & Shooting in Austin, TX only gunman killed \\
\hline May 2015 & Elton Simpson \& Nadir Soofi & $\begin{array}{c}\text { Shooting at the Curtis Curtwell Center in } \\
\text { Garland, TX injuries, no deaths }\end{array}$ \\
\hline June 2015 & Dylann Roof & $\begin{array}{c}\text { Shooting at the SC Emanuel African Methodist } \\
\text { Episcopal Church in Charleston, SC. Killed 9, } \\
\text { injured } 1\end{array}$ \\
\hline November 2015 & Robert L. Dear & $\begin{array}{c}\text { Shooting at Colorado Springs Planned } \\
\text { Parenthood killing 3, injuring } 9\end{array}$ \\
\hline December 2015 & Rizwan Farook \& Tashfeen Malik & $\begin{array}{l}\text { Shooting in San Bernadino, CA } 14 \text { killed, } \\
22 \text { injured }\end{array}$ \\
\hline June 2016 & Omar Mateen & Shooting in Orlando, FL 49 killed, 53 injured \\
\hline July 2016 & Muhammad Youssef Abdulazeez & $\begin{array}{l}\text { Shooting at the Chattanooga, TN Military } \\
\text { Installation killing 5, injuring } 2\end{array}$ \\
\hline
\end{tabular}

Similar to the prior study, national media coverage for the two weeks immediately following each terrorist event was collected, including the New York Times, Washington Post, USA Today, CNN, $M S N B C$, and FOX News. The study focused on news articles only, excluding letters to the editor and editorials. The researchers collected all stories on LexisNexus and websites for each organization, resulting in 882 news stories. In phase one of the study, the stories were read by two researchers to understand the tone and content of the coverage. In phase two, both researchers read each article and independently charted key themes within the articles, with a key theme being a repeated or emphasized idea. Both researchers found common themes, so in phase three, the lead researcher read the articles again, noting specific examples of each theme in the articles. The themes that emerged were: Description of the agent, motive for the act, victim as good/terrorist as evil, and tool used for the act. 


\section{Description of the Agent}

The majority of coverage of an act of terrorism is identifying who committed the act and attempting to describe them and their background to get at the question of why. In coverage of the 11 acts in this study, there was a clear difference in how Muslim agents with international ties were reported on versus those with no international ties. A key difference from Powell's 2011 study was that all five of the 11 terrorist acts committed by Muslims were U.S. citizens motivated by international terrorist groups, with most born and raised in the U.S. The other six acts were committed by U.S. citizens with no reported international ties.

\subsection{Domestic Agents}

U.S. Citizens with no ties to other countries are typically identified by name only and are not always labeled as terrorists initially. For the shootings at LA Airport, the Overland Park Jewish Center, Las Vegas, Austin, the South Carolina Church, and the Planned Parenthood clinic in Colorado, the agents were U.S. citizens with no international ties and thus the acts tended to initially be labeled as isolated acts of a troubled individual or hate crimes, versus terrorism, though most meet the definition of terrorism cited earlier in this paper. This began a debate in some cases over the label: "Abortion rights groups are pressuring federal officials to treat Friday's attack on a Planned Parenthood clinic as an act of domestic terrorism" (Hughes 2015). Cases where many were killed or the act was very public and extreme are eventually labeled domestic terrorism, as was the case in the shooting in downtown Austin where 100 rounds were fired. Overall, however, the label terrorism is more quickly given to acts committed by those with international and Islamic connections, while the coverage of acts by domestic agents turns to talking with families to discover more about the individual, as well as why they may have committed the act.

The why for "terrorists" who were domestic born without international ties was that they were troubled, mentally ill loners. For example, the Shooter of the Planned Parenthood clinic's ex-wife described "Mr. Dear as a serial philanderer and a problem gambler, a man who kicked her, beat her head against the floor and fathered two children with other women while they were together. He found excuses for his transgressions, she said, in his idiosyncratic views on Christian eschatology and the nature of salvation" (Fausset et al. 2015). The Washington Post headline described him as "adrift and alienated" (Wan 2015). In addition to being alienated and loners, perpetrators' families typically were reported as not having suspected that their family member would commit such an act. In the church shooting in South Carolina, Dylan Roof's family was shocked by his act and said, "We didn't see this coming" (Bergman 2015). Of the shooter at LAX, a neighbor said, "He was never weird toward me. He never gave me any weird vibes" (Associated Press 2013c).

Overall, there was much less coverage of incidents if the perpetrator had no Islamic ties. In the Austin shooting, there was little coverage of the shooter, McQuilliams. He fired 100 rounds in 10 minutes in downtown Austin and was described by police as a "'homegrown American extremist' with ties to a Christian identity hate group" (Ohlheiser and Izadi 2014). He had no criminal record or international ties, and though he had an anti-government agenda, he was not labeled as a terrorist until late in the investigation.

In the case of Dylan Roof, the white man charged in the Charleston, S.C. shooting at a black church, the incident was immediately identified as a hate crime, though not as terrorism: "The shooting of nine people by a white gunman inside a black church comes amid a recent surge in violent hate groups and incidents, in which 'lone wolf' attacks are increasingly common, according to groups who monitor hate crimes" (Jervis 2015). Similarly, the Kansas City Jewish Center act was labeled a hate crime, with terrorism being mentioned by few: "The suspect, 73, is a former Ku Klux Klan leader with a history of anti-Semitism and racism, according to the Southern Poverty LawCenter, a civil rights organization that tracks hate groups" (Fitzsimmons 2014). 
In sum, non-Muslim U.S. citizens with no international terrorist group ties were frequently described as individual, angry loners with mental illness who posed no future threat to the U.S. population.

\subsection{International Agent}

As opposed to Powell's 2011 finding, for terrorist acts from 2011-2016, time was taken to discover the background of a perpetrator before labeling them Muslim or the act as terrorism, though connections to Islam were present early, as were investigations into possible Islamic connections. For example, in the shooting at their workplace in California, reporting described the male as a U.S. citizen who brought his wife to the U.S. from the Middle East, and though halted before labeling the event terrorism, made international ties and identified ethnicity: "The suspects' extensive arsenal, their recent Middle East travel and evidence that one of them had been in touch with people with Islamist extremist views, both in the United States and abroad, all contributed to the decision to refocus the investigation. But officials emphasized that they did not know what set off the attack, and said that they were not ready to call it terrorism" (Medina et al. 2015). Similarly, investigating the Boston Marathon bombing took several days to identify the suspects, yet in the meantime, the media theorized about Islamic ties: "A Moscow media report reveals new details about the Islamic interests and online activity of the Chechen brothers linked to Monday's Boston Marathon bombing" (Russian Media 2013). In the case where not much is yet known, the perpetrator is identified by their ethnicity, which can play into assumptions in the public of a connection to Islam, such as "24-year-old Kuwaiti-born gunman opened fire on a military recruiting station on Thursday, then raced to a second military site where he killed four United States Marines, prompting a federal domestic terrorism investigation" (Fausset et al. 2015). Agents were not as quickly labeled terrorists as previously, perhaps indicating a desire to confirm before labeling, yet international connections to Muslim countries were made and once confirmed, the focus on religion and a threat on the U.S. from a larger group began, such as when Fox News' Bill O'Reilly stated, "More Americans die at the hands of Muslim extremists" (O'Reilly 2015).

In the Texas shooting on an anti-Islam group Prophet Mohammed cartoon contest, the identification of the suspects as Muslim was immediate, because they were known: "One was an extrovert drawn to basketball as well as to Islam, who had been identified by the F.B.I. as a jihadist terrorism suspect and was once a regular at Friday Prayer at a mosque near his Phoenix apartment. The other was more quiet, ran a carpet cleaning business in Phoenix and often prayed at the same mosque" (Fernandez et al. 2015b). In coverage of this attack, as is consistent in this analysis, once confirmation and investigation of Islamic connections was sought, the terrorist label was used.

International ties of the perpetrators was a key theme in this study. Once suspicion of a Muslim identity occurred, an investigation ensued to uncover the nature of those ties. In the attack on their workplace, it was reported that, "Investigators have found evidence that Farook, an American citizen with Pakistani parents, and Malik, a Pakistani national, had become radicalized before their July 2014 marriage, talking online about jihad and martyrdom before meeting each other in person" (Schuppe 2015). Similarly, they were described as being "radicalized" (Nagourney et al. 2015b), with Malik declaring "allegiance to the Islamic State on Facebook around the time of the attack" (Ryan et al. 2015). Significant coverage was spent attempting to determine if this was a terrorist act or a result of anger in the workplace; however, the focus on connections to Islam became salient descriptors, ultimately leading to defining the act as one of terror motivated by connections outside of the U.S. (Ryan et al. 2015).

Though criticized by Fox News, President Obama was perhaps a leading cause to the careful connection of terrorist acts to Islam. Of the San Bernadino case, they wrote "throughout the week, the president stubbornly refused to acknowledge even the existence violent Islamic extremism" (McFarland 2015). Similarly, Donald Trump, before it was discovered that Omar Mateen, the Florida nightclub gunman, had expressed an allegiance to the Islamic State, "declared President Barack Obama should resign if he did not use the words 'radical Islamic terrorism' to label the massacre" 
(Fox News 2016). The pressure to label an act by a Muslim as "terrorism" was great given the media framing that had already been established in the coverage of terrorist acts since 9/11 (Powell 2011).

\section{Motive for Act}

After a terrorist act, an attempt to answer "why" became the focus. Media coverage attempted to identify a motive for the attacks, which differed for domestic versus international terrorists. Domestic agents with no international ties, as discussed earlier, were described as having mental illness, anger, and were loners, and were thus excused early in coverage from being a larger threat to the U.S. population, so no further motive was investigated. This resulted in less media coverage; whereas, those with international ties had motives tied to the mission of Islamic terrorist organizations, making them more of a threat. What became challenging in this cycle of terrorist acts was U.S. born perpetrators whose ethnicity was from a country with an Islamic presence. Unlike domestic terrorists with no international ties, terrorists who were Muslim always had a connection and motivation outside of the U.S. prompting their actions, intensifying the fear of the "other". Because all five terrorist events committed by Muslims were U.S. citizens, the fear from within was intensified and reporting investigated why a U.S. citizen would commit an act of terror.

The Boston Marathon bombing "raised alarms that terrorists might have struck again in the U.S." (Associated Press 2013b), yet when it was discovered that the bombers were U.S. born, the search for a motive became more challenging. Similarly, for 24-year-old gunman Mohammod Abdulazeez's attack in Tennessee, "As the F.B.I. sent more investigators into this city Monday to explore dozens of possible leads, a picture took shape of a deeply troubled young man who struggled with mental illness and drug abuse at the same time he found himself alienated from United States policies in the Arab world, according to the authorities, friends and the family representative" (Fernandez et al. 2015a). Media reported on his recent trip to Jordan and his struggle with his American and Muslim identity. Friends said that when he returned he was different (Brumfield and Zamost 2015). Furthermore, "Dozens of Twitter accounts spewing jihadist bile have placed Mohammad Abdulazeez's bearded face as their main images, and tweets believed to have been sent out by Islamic State radicals and sympathizers have proclaimed him a martyr" (Zimmerman 2015). While mental illness was mentioned, the connection to Islam was stronger in media coverage: "Abdulazeez had a hard time keeping a job because of his manic depressive/bipolar disorder and drug use, for which he had sought treatment with a psychiatrist, according to the source familiar with the family's interviews"' (Zamost et al. 2015).

The San Bernardino shooting was particularly perplexing given that a woman was one of the shooters and the couple was married, with a six-month-old child, and they seemed to be living the American Dream, yet once a connection was made to Islam, the motive seemed more clear for why they would have committed "the single deadliest terrorist attack on U.S. soil or on U.S. citizens-since 11 September 2001" (McFarland 2015). Connections between Islam and terrorism become salient when occurring across events. After the shooting in Dallas, it was reported that, "In a broadcast on its official radio channel Tuesday, the group said two Al Khilafa soldiers opened fire outside the event in Garland, a Dallas suburb. Al Khilafa is how ISIS refers to its soldiers" (Yan 2015). Before suspects had been identified in the Boston Marathon bombing, a connection to al-Qaeda and potential training of terrorists ensued. An al-Qaeda publication "Inspire" was cited as including "instructions for building a homemade explosive out of a pressure cooker exactly the sort of device that appears to have been used at Monday's Boston Marathon bombings. More than $24 \mathrm{~h}$ later, with no indication yet that authorities know who committed the attack, some are, understandably wondering if this apparent connection might suggest al-Qaeda's hand" (Fisher 2013). So even without suspect identification, a connection had been made to Islam and fear from Muslims abroad heightened.

In sum, each terrorist act committed by an individual with a name connected ethnically to a country with a significant Muslim population was found to have a connection to an international terrorist organization, no matter how minor, thus connecting Muslims and Islam to terrorism and a desire from those outside the U.S. to harm those within it. 


\section{Victim as Good/Terrorist as Evil}

Identical to Powell 2011 study, victims were described as heros, innocent, and good family people who were surprised by an evil or sick individual as part of a terrorist act. Though the victims of terrorist acts were not specifically targeted, they were pitted against the terrorist in a US versus them mentality. In the LA Airport shooting, the US versus them mentality is clear: "One was a troubled 23-year-old, with an assault rifle and an apparent grudge against the government, who witnesses said seemed to be hunting for airport security officials. The other was a 39-year-old father of two who for three years had been a screener of the torrent of passengers who move through the security lines at Los Angeles International Airport" (Medina and Lovett 2013).

\subsection{Hero}

Coverage of victims focused on the roles of those who were heroes in trying to stop the terrorist act. The victims were the embodiment of good, fighting the evil terrorists. For example, in coverage of the San Bernardino incident: "Shannon Johnson was fun, loving and kind, his girlfriend said. So much so, that his last gesture on Earth was one of kindness. One of the survivors of the massacre said Johnson covered her during the shooting and was her hero. 'I got you,' co-worker Denise Peraza said he told her as he shielded her from bullets" (Karimi 2015).

In the Charleston Church shooting, many heroes were created, such as "When Tywanza Sanders, the poet and peacemaker of the family, saw the man draw his gun during Bible study and point it as his elderly aunt, Susie Jackson, he shielded her and tried to talk the gunman into laying down his weapon, a relative said Thursday" (Alvarez and Blinder 2015). Victims became one dimensional heros, representing all that is good about America in the face of the evil of the terrorists.

\subsection{Good and Innocent}

Though victims are certainly multidimensional, their goodness and innocence was focused on in media coverage, including their roles in their families and communities. In the San Bernardino shooting, "Gabriel Torres said his wife, Carina, a social worker who works at the center, spent half an hour or more on the phone with him as she hid under her desk, crying, after her supervisor told her to take cover. Terrified, Ms. Torres told him that he should make sure to take care of their four daughters, ages 10 to 24, if anything were to happen to her" (Nagourney et al. 2015a). Similarly, Garrett Swasey, who was shot and killed at the Planned Parenthood office, was described "as a courageous man and loving father who drew strength and inspiration from his Christian faith" (Victor and Healy 2015). In other attacks, victims were described as "Army veteran and a lovable mother" (Fieldstadt 2015), "a giant, a legend, a moral compass" (Diebel 2015), and "served a total of five tours in Iraq and Afghanistan, and one was awarded the Purple Heart" (Kube 2015). All victims were good and innocent individuals.

\subsection{Terrorist as Evil}

Whether mentally ill, a loner, or having international ties to terrorism, the terrorist in each case was described as evil in taking innocent lives. Roof, in shooting members of the Episcopal Church in South Carolina, was described as deceptive in attending church and then opening fire, after writing about the intention to kill black people (Robles et al. 2015). Mateen was said to have attacked a gay nightclub out of hatred for gay people (Solis and Young 2016). While some were defined as individually evil or full of hatred, in some cases, part of defining a terrorist as evil was connecting them with a larger group that has an agenda against the U.S., hence creating an us versus evil them mentality. In the San Bernardino shooting, "One was associated with Shabab, the Islamist militant movement in Somalia, and another with the Nusra Front, the wing of Al Qaeda in Syria" (Hauser 2015). As discussed earlier, connections to ISIS an Al Qaeda were common links in the coverage of Muslims who committed terrorist acts. 


\section{Tool Used/Gun Control Debate}

A new theme in this coverage versus Powell 2011 study was a focus on the tool used to commit the act, particularly when the tool was a gun. Despite efforts by Obama to pass gun legislation in 2013, the Senate defeated the bill (Landler 2013). Therefore, the gun control debate heightened with each act involving guns.

Coverage of all events using a gun discussed how guns were obtained. In the San Bernardino shooting, the semiautomatic rifles were obtained legally in spite of strict California gun laws (McIntire 2015): “The rifles were variants of the popular AR-15, the semiautomatic civilian version of a military M-16. They are surprisingly easy to acquire in California, though they come with limitations aimed at curbing their ability to inflict mass damage." This led to a debate over the need for a better regulation of assault rifles and semiautomatic weapons (Gun Laws 2015; Horwitz 2015). Similarly, "A firearm that the authorities said was used on Sunday in a mass shooting at a nightclub in Orlando, Fla., is a descendant of one of the world's most widely distributed and familiar infantry weapons, and a type of rifle that has been involved in previous mass shootings in the United States" (Chivers 2016). The Charleston shooting enraged gun control advocates, who argued that there were not gun laws to prevent Dylan Roof from purchasing his gun legally (Borden et al. 2015; Costa 2015). The Tennessee shooter purchased some guns legally and others illegally (Botelho et al. 2015). Additionally, the Kansas City shooter had "obtained firearms from a 'straw buyer,' a middleman with a clean record who could buy weapons legally and then sell or give them to Cross, allowing Cross to avoid federal background checks, a U.S. law enforcement official said. He had three guns when he was arrested Sunday, authorities said" (Ahmed et al. 2014).

Obama responded to each incident, including responding "angrily on Saturday to the mass shooting that took three lives, including that of a police officer, at a Planned Parenthood facility in Colorado Springs over the Thanksgiving holiday, calling the country's recurring outbreaks of gun violence 'not normal'" (Martin 2015). This particular incident was used to support stricter laws given that the shooting was of armed officers: "So much for the argument that having more people armed in public places will result in fewer gun deaths" (Parker 2014).

Only one of the eleven terrorist acts in this study did not use a gun-the Boston Marathon bombing. Ten acts used guns, thus fueling the gun control debate already well underway following many school shootings.

\section{Discussion}

Four themes emerged in this study, with three similar to Powell 2011 study: description of the agent, motive for the act, and portrayal of the victim(s). The theme from the first study that did not emerge in this study was "probability of a future act," perhaps because 10 of 11 of the terrorist acts in this study were committed by guns, the increase in gun violence in the U.S. has become the new normal so the probability is always there, and the fear of Islam is so engrained that there is always fear of a terrorist attack. Both Powell 2011 study and the current study of media coverage of terrorism in the U.S. identified a clear pattern of media coverage of Islam feeding Orientalism and fear of Islam, or an us versus them mentality, though in this study, the "us" was U.S. citizens with international ties.

Mediated images of terrorism continue to serve an "essentializing" function (Shah and Thornton 1994) intimately connecting terrorism with Islam and Muslims. Those U.S. citizens with no international ties were in some way "excused" for their behavior due to mental illness and access to guns, or in cases of hate crimes, seen as fueled by irrational anger; whereas Muslims committing terrorist acts were connected with a larger network of terrorist groups with a goal of attacking America.

The pattern of coverage in this study varied slightly from that in Figure 1 from Powell 2011 study in that an event was not immediately labeled as terrorism and the perpetrator was labeled as Muslim. Rather, once a terrorist event occurred, the perpetrator was first labeled Muslim or non-Muslim before the reason for the act was investigated. If the perpetrator was not Muslim, they were frequently 
described as an angry loner with mental illness who was part of the gun violence culture in the U.S. If the perpetrator is Muslim, connections to international Islamic terror groups are investigated and the war of Islam on the U.S. is furthered (Figure 2), widening the East/West divide promoting Islamic terror and Muslims as the "other" (Semati 2010).

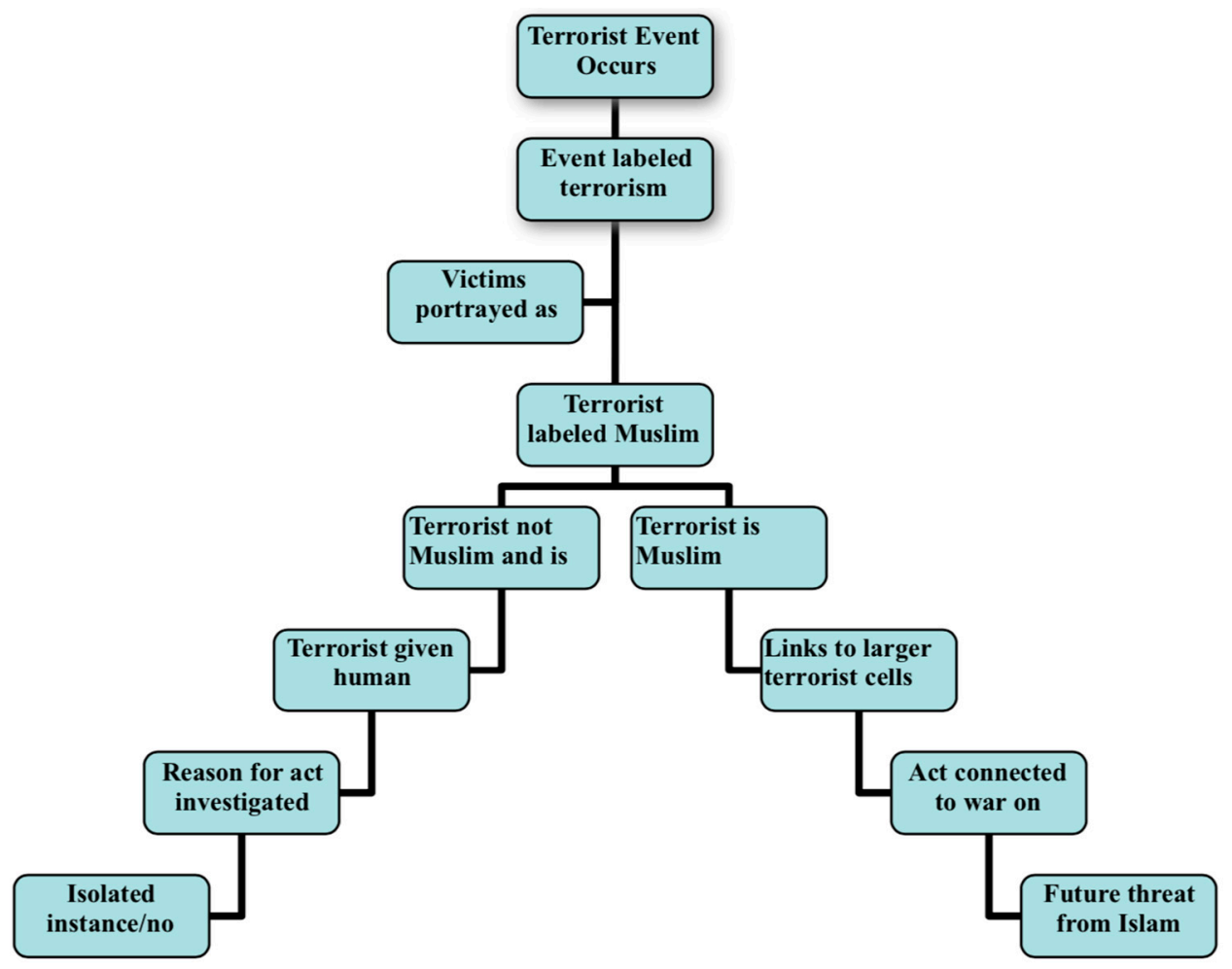

Figure 1. Model of media coverage of terrorist events in the U.S. (Powell 2011).

Ironically, since terrorist acts depend on media to spread fear, the media coverage of acts of terror in this way is aiding Islamic terrorists in their goal of creating fear. Tuman (2010) argued that terrorism is a communication act with various audiences: victims, the U.S. government, and the larger population. Media coverage of terrorist acts helps achieve the final goal by inciting fear. As media frames grow and become accepted, they can impact the political response, such as when President Obama addressed the nation about efforts to combat terrorism after the San Bernardino event, given ties to international terrorist groups (Wagner 2013). The media frame becomes an exigence requiring a political response to assure the public that actions are being taken to keep them safe.

This study shows the media frame that was found in Powell's 2011 study continues in that coverage of terrorist acts is programmatic and creates and sustains a "thematic frame of terrorism: war of Islam on the U.S." (Powell 2011). In the terrorist acts from 2011-2016, because of the extended focus on terrorists who were Muslim and U.S. citizens, the threat from Islam is even greater because terrorists are living among us. For acts of domestic terrorism with no international ties, the news coverage of the event was brief, whereas acts carried out by Muslims with "international" ties prolonged the coverage. There were 237 news articles for the six incidents of terrorism with no international connection, compared with 645 articles for the five incidents by Muslims with international connections. Approximately three times as much coverage of Muslim terrorist acts heightens fear and not only keeps Orientalism alive (Said 1978), but intensifies the resulting fear of Islam. 


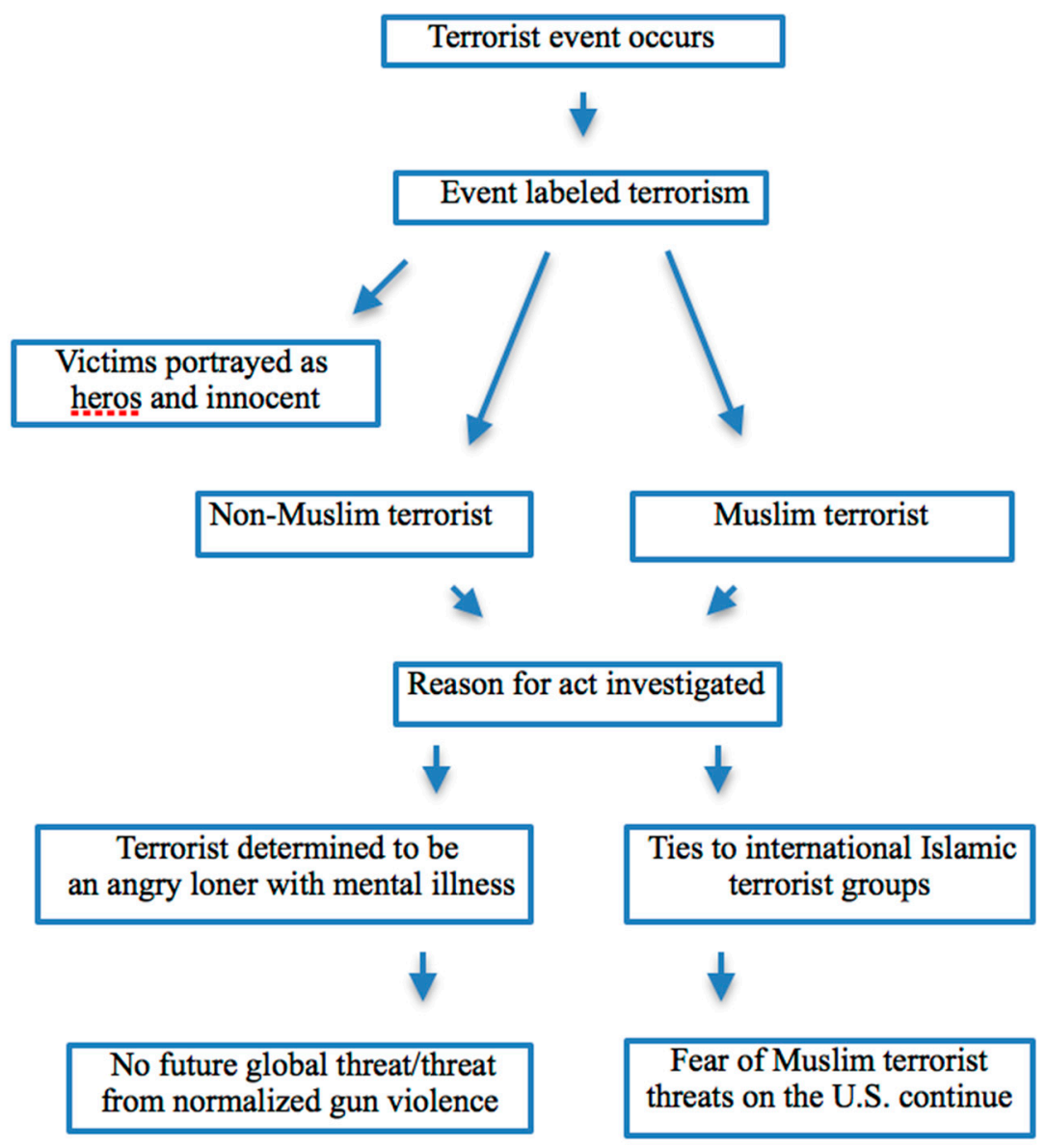

Figure 2. Model of media coverage of terrorist events from 2011-2016.

In the six years since Powell (2011) initial framing study, this study found that the media continue to frame domestic terrorism as isolated incidents of troubled individuals, and "Islamic" terrorism as a larger problem from Muslims connected to international terror groups-who are also U.S. citizens. This media framing fuels anti-Muslim sentiment in the U.S., as Bail (2012) found that anti-Muslim organizations that were formerly fringe organizations were now in the mainstream in terms of contributing to media framework coverage. This media framing also has the potential to impact political decision making and global relations between the U.S. and Islamic countries. Saleem et al. (2017) found that those consuming anti-Muslim coverage were more likely to support restricting civil liberties of Muslims and military actions in Muslim countries. This can be seen in the differences of how Obama paused before using the term "terrorist" and would not use "Islamic" and "extremism" together, whereas, Trump seems to have adopted the us versus them terrorist frame, which has impacted his policies, including travel bans on individuals from Muslim countries.

Due to the vast nature of mass media and the power of framing, "Muslims are mediated beings in ways beyond their control ... . in reductive and monolithic ways (Bowe and Makki 2016, p.15). With the majority of media coverage of terrorist acts focusing on those by Muslim Americans (though that is only five of the 11 terrorist acts in the last six years), this media framing poses a particular challenge: "As Muslim-Americans work to carve out a hybrid identity, a key part of their struggle will be challenging the dominant media discourse that insists on the incompatibility of the two parts of that hyphenated identity" (Bowe and Makki 2016, p. 15). It calls into question the primary identity and allegiance of Muslim Americans in a media frame of Islam versus the U.S., thus perpetuating questions of identity and being a "real American." 
Media framing of Muslims as terrorists has been fairly consistent since 9/11 and has an impact within the U.S. on Muslim Americans and how others see them. This study argues that terrorists who are Muslim are framed differently than those who are not Muslim, adding to a fear of the "other" that intensifies with each terrorist event. The dominance of the U.S. media globally adds to the power of this frame to impact global relations with Islamic countries. As Khan et al. (2012) have warned, "Negative portrayal of Muslims in the Western media is globalized and if allowed to continue may eventuate into some kind of clash of civilizations with horrendous consequences for human civilization on the planet" (p. 5).

Funding: This research was funded by a Luther College Faculty/Student Research Grant.

Conflicts of Interest: The authors declare no conflict of interest.

\section{References}

Ahmed, Saeed, Ed Lavandara, and Catherine E. Shoichet. 2014. Alleged Kansas Jewish Center Gunman Charged with Murder. CNN, April 15. Available online: http://www.cnn.com/2014/04/15/us/kansas-jewishcenter-shooting/index.html (accessed on 16 November 2016).

Alvarez, Lizette, and Alan Blinder. 2015. Recalling nine spiritual mentors, gunned down during night of devotion. The New York Times, June 18. Available online: http:/ / search.proquest.com/usnews/docview/1689794150/ 30E34852CD124828PQ/34?accountid=27921 (accessed on 10 February 2017).

Associated Press. 2013a. 2 Dead, More than 130 Injured as 2 Bombs Explode near Boston Marathon Finish Line. Fox Newws, April 15. Available online: http:/ /www.foxnews.com/us/2013/04/15/3-dead-more-than-130injured-as-2-bombs-explode-near-boston-marathon-finish.html (accessed on 3 March 2017).

Associated Press. 2013b. What Is 'Terrorism'? Boston Bombings Renew Efforts to Define Pain, Motives in a Single Word. Fox News, April 18. Available online: http:/ / www.foxnews.com/us/2013/04/18/what-is-terrorismboston-bombings-renew-efforts-to-define-pain-motives-in.html (accessed on 17 November 2016).

Associated Press. 2013c. Los Angeles Airport Shooting Suspect Had Sent Suicidal Text to Sibling, NJ Police Chief Says. Fox News, November 2. Available online: http:/ /www.foxnews.com/us/2013/11/02/los-angelesairport-shooting-suspect-had-sent-suicidal-text-to-sibling-nj.html (accessed on 16 July 2017).

Bail, Christopher A. 2012. The Fringe Effect: Civil Society Organizations and the Evolution of Media Discourse about Islam since the September 11th Attacks. American Sociological Review 77: 855-79. [CrossRef]

Bergman, Jesse. 2015. Charleston Massacre Suspect's Uncle: “I Hope He Gets What's Coming to Him". MSNBC, June 18. Available online: http:/ /www.msnbc.com/hardball/charleston-massacre-suspects-uncle-i-hopehe-gets-whats-coming-him (accessed on 16 July 2017).

Borden, Jeremy, Sari Horowitz, and Jerry Markon. 2015. From Victims' Families, Forgiveness for Accused Charleston Gunman Dylann Roof. The Washington Post, June 19. Available online: http://search. proquest.com/usnews/docview/1689974007/763706A7ECA9457BPQ/12?accountid=27921 (accessed on 18 July 2017).

Botelho, Greg, Ralph Ellis, and Victor Blackwell. 2015. 4 Guns Seized after Chattanooga Shooting, Official Says. CNN, July 17. Available online: http://www.cnn.com/2015/07/17/us/tennessee-naval-reserve-shooting/ index.html (accessed on 17 July 2017).

Bowe, Brian J., and Taj W. Makki. 2016. Muslim neighbors or an Islamic threat? A constructionist framing analysis of newspaper coverage of mosque controversies. Media, Culture \& Society 38: 540-58.

Brumfield, Ben, and Scott Zamost. 2015. Chattanooga Shooter Changed after Mideast Visit, Friend Says. CNN, July 17. Available online: http:/ /www.cnn.com/2015/07/17/us/tennessee-shooter-mohammad-youssufabdulazeez/index.html (accessed on 17 November 2017).

Brummett, Barry. 1994. Rhetoric in Popular Culture. New York: St. Martin's Press.

Chesebro, James W., and Dale A. Bertelsen. 1996. Analyzing Media: Communication Technologies as Symbolic and Cognitive Systems. New York: Guilford Press.

Chivers, Christopher John. 2016. Man Used Assault Rifle with Military Roots. New York Times, June 13. Available online: http:/ / proxy.luther.edu/login?url=http:/ / search.proquest.com.proxy.luther.edu/docview / 1795815802?accountid=27921 (accessed on 5 July 2016). 
Costa, Robert. 2015. Shaken Charleston Mayor: 'Far Too Many Guns out There'. The Washington Post, June 18. Available online: http:/ / search.proquest.com/usnews/docview/1689968133/763706A7ECA9457BPQ/23? accountid=27921 (accessed on 7 July 2018).

Diebel, Matthew. 2015. Slain Rev. Pinckney Described as 'a Giant'. USA Today, June 18. Available online: http:/ / search.proquest.com/usnews/docview/1689884054/5A195E1505224D48PQ/15?accountid=27921 (accessed on 13 November 2016).

Entman, Robert M. 1989. Democracy without Citizens: Media and the Decay of American Politics. New York: Oxford University Press.

Entman, Robert M. 1993. Framing: Toward clarification of a fractured paradigm. Journal of Communication 43: 51-58. [CrossRef]

Entman, Robert M., and Andrew Rojecki. 1993. Freezing out the public: Elite and media framing of the US anti-nuclear movement. Political Communication 10: 151-67. [CrossRef]

Fausset, Richard, Blinder, and Michael Schmidt. 2015. Gunman Kills 4 at Military Site in Chattanooga. The New York Times, July 16. Available online: http:/ / search.proquest.com/usnews/docview/1696831931/ A27F6589F99048D5PQ/1?accountid=27921 (accessed on 7 July 2018).

Fernandez, Manny, Alan Blinder, Eric Schmitt, and Richard Perez-Pena. 2015a. In Chattanooga, Young Man in Downward Spiral. The New York Times, July 20. Available online: http://search.proquest.com/usnews/ docview /1697379481/A27F6589F99048D5PQ/9?accountid=27921 (accessed on 16 November 2016).

Fernandez, Manny, Richard Perez-Pena, and Juan Santos. 2015b. Gunman in Texas Shooting Was F.B.I. Suspect in Jihad Inquiry. The New York Times, May 4. Available online: http:/ / search.proquest.com/usnews/docview / 1712371966/67B342B312A448FDPQ/1?accountid=27921 (accessed on 13 November 2016).

Fieldstadt, Elisha. 2015. Victims of Planned Parenthood Shooting Identified as Mother of Two, Army Veteran. MSNBC, November 29. Available online: http:/ / www.msnbc.com/msnbc/victims-planned-parenthoodshooting-identified-mother-two-army-veteran (accessed on 7 July 2017).

Fisher, Marc. 2013. Knowledge of Pressure-Cooker Bombs Is Not Limited to Readers of Al-Qaeda's 'Inspire' Magazine. The Washington Post, April 16. Available online: http:/ / search.proquest.com.proxy.luther.edu/ usnews / docview /1327617658/3556A25991974C84PQ/126?accountid=27921 (accessed on 6 July 2018).

Fitzsimmons, Emma G. 2014. Man Kills 3 at Jewish Centers in Kansas City Suburb. The New York Times, April 13. Available online: http:/ / search.proquest.com/usnews/docview/1515621422/5BC4AE39331046CEPQ/1? accountid=27921 (accessed on 3 July 2016).

Gitlin, Todd. 1980. The Whole World Is Watching: Mass Media in the Making E Unmaking of the New Left. Berkeley: University of California Press.

Goffman, Erving. 1974. Frame Analysis: An Essay on the Organization of Experience. New York: Harper \& Row, pp. 10-11.

Gun Laws. 2015. Gun Laws and the San Bernardino Shooting (Posted 2015-12-08 23:00:18). The Washington Post, December 8. Available online: http:/ / proxy.luther.edu/login?url=http:/ / search.proquest.com.proxy.luther. edu/docview /1746801671? accountid=27921 (accessed on 16 July 2017).

Hauser, Christine. 2015. San Bernardino Shooting: The Investigation So Far. The New York Times, December 4. Available online: http://search.proquest.com.proxy.luther.edu/docview/1739286825/ 1DFF9FAEC3B547CDPQ/12?accountid=27921 (accessed on 18 July 2016).

Horwitz, Sari. 2015. Guns Used in San Bernardino Shooting Were Purchased Legally from Dealers (posted 2015-12-03 18:50:39). The Washington Post, December 3. Available online: http:/ / proxy.luther.edu/ login?url=http:/ / search.proquest.com.proxy.luther.edu/docview /1739002272?accountid=27921 (accessed on 16 July 2016).

Hughes, T. 2015. Planned Parenthood suspect in court. USA Today, November 30. Available online: http:/ / web. a.ebscohost.com.proxy.luther.edu/ehost/ detail/detail?sid=153b075d-70c8-4e3d-b290-5b6cc8d1d20d\% 40sessionmgr4005\&vid=0\&hid=4209\&bdata $=J n N j b 3 B 1 P X N p d G U \% 3 d \# A N=J 0 E 188122714415 \& d b=a 9 h$ (accessed on 27 August 2016).

Huntington, Samuel P. 1993. The clash of civilizations? Foreign Affairs 72: 22-49. [CrossRef]

Iyengar, Shanto, and Adam Simon. 1993. News coverage of the Gulf crisis and public opinion: A study of agenda-setting, priming, and framing. Communication Research 20: 365-83. [CrossRef]

Jamieson, Kathleen Hall, and Paul Waldman. 2003. The Press Effect: Politicians, Journalists and the Stories that Shape the Political World. New York: Oxford University Press. 
Jervis, Rick. 2015. Hate in America: Study of Violence Spots Rise in 'Lone Wolf' Attacks. USA Today, June 19. Available online: http:/ / search.proquest.com/usnews/docview/1689883957/5A195E1505224D48PQ/13? accountid=27921 (accessed on 13 November 2016).

Karimi, Faith. 2015. San Bernardino Shooting: Who Were the Victims? CNN, December 3. Available online: http:/ / www.cnn.com/2015/12/03/us/san-bernardino-shootings-victims/index.html (accessed on 16 November 2016).

Kube, Courtney. 2015. Chattanooga Shooting: Marines ID Victims, Including Recipient of Purple Heart. MSNBC, July 17. Available online: http://www.msnbc.com/msnbc/chattanooga-shooting-marines-id-victimsincluding-recipient-purple-heart (accessed on 18 July 2016).

Khan, Rahim F., Zafar Iqbal, Osman Gazzaz, and Sadollah Ahrari. 2012. Global media image of Islam and Muslims and the problematics of a response strategy. Islamic studies 51: 5-25.

Landler, Mark. 2013. A Setback Met by Anger, Another by Resolve. New York Times, April 18. Available online: http:/ / search.proquest.com/usnews/docview/1328446942/fulltext/5C26485E56744E4DPQ/38? accountid=27921 (accessed on 15 July 2016).

Markham, James W., and Crispin Maslog. 1971. Images and the mass media. The Journalism Quarterly 48: 519-25. [CrossRef]

Martin, Jonathan. 2015. Obama Says 'Enough Is Enough' after Colorado Shooting. New York Times, November 29. Available online: http://www.nytimes.com/2015/11/29/us/colorado-springs-planned-parenthoodobama-responds-to-gun-violence.html (accessed on 1 August 2016).

McFarland, Kathleen Troia. 2015. After San Bernardino: How Political Correctness Could Get Us All Killed. Fox News, December 4. Available online: http://www.foxnews.com/opinion/2015/12/04/after-sanbernardino-how-political-correctness-could-get-us-all-killed.html (accessed on 5 July 2016).

McIntire, Mike. 2015. Weapons in San Bernardino Shootings Were Legally Obtained. New York Times, December 3. Available online: http://search.proquest.com.proxy.luther.edu/docview/1738904731/ 1DFF9FAEC3B547CDPQ/7?accountid=27921 (accessed on 7 July 2017).

Medina, Jennifer, and Ian Lovett. 2013. 2 Lives Collide in Fatal Instant at Busy Airport. New York Times, November 2. Available online: http://search.proquest.com/usnews/docview/1447993527/fulltext/ E76071BC11504B66PQ/2?accountid=27921 (accessed on 9 July 2017).

Medina, Jennifer, Richard Perez-Pena, Michael S. Schmidt, and Laurie Goodstein. 2015. San Bernardino Suspects Left Trail of Clues, But No Clear Motive. Available online: http://search.proquest.com.proxy.luther. edudocview1738904701/1DFF9FAEC3B547CDPQ/4?accountid=27921 (accessed on 11 July 2017).

Miller, Judith. 2013. A Desire to Be Part of an 'Epic Struggle'-A New Profile of Jihadists. Fox News, April 18. Available online: http:/ / www.foxnews.com/opinion/2013/04/18/stray-dogs-not-lone-wolvesnew-profile-jihadis.html (accessed on 14 July 2016).

Fox News. 2016. Orlando shooting revives a fight over 'Islamic' label. Fox News, June 13. Available online: http:/ / www.foxnews.com/us/2016/06/13/orlando-shooting-revives-fight-over-islamic-label.html (accessed on 13 June 2016).

Nagourney, Adam, lan Lovett, and Richard Perez-Pena. 2015a. San Bernardino Shooting Kills at Least 14; Two Suspects Are Dead. Available online: http://search.proquest.com.proxy.luther.edu/docview/ 1738828313/1DFF9FAEC3B547CDPQ/21?accountid=27921 (accessed on 19 July 2016).

Nagourney, Adam, Salman Masood, and Michael S. Schmidt. 2015b. Killers Were Long Radicalized, F.B.I. Investigators Say. Available online: http: / / search.proquest.com.proxy.luther.edu/docview /1744903863/ 1DFF9FAEC3B547CDPQ/47?accountid=27921 (accessed on 23 July 2016).

Norris, Pippa, Montague Kern, and Marion Just. 2003. Framing Terrorism. New York: Routledge Press.

O'Reilly, Bill. 2015. More Americans Die at the Hands of Muslim Extremists. Fox News, December 4. Available online: http:/ / www.foxnews.com/transcript/2015/12/04/bill-oreilly-more-americans-die-at-hands-Muslimextremists / (accessed on 2 July 2016).

Ohlheiser, Abby, and Elahe Izadi. 2014. Police: Austin Shooter Was a 'Homegrown American Extremist'. The Washington Post, December 1. Available online: http://search.proquest.com/usnews/docview/ 1629483461/1859B074198E410DPQ/2?accountid=27921 (accessed on 6 July 2016). 
Parker, Kim. 2014. Armed and Dead. The Washington Post, June 10. Available online: http:/ / search.proquest.com/ usnews / docview /1534422698/CCA0AB3EAA774D73PQ/6? accountid=27921 (accessed on 9 July 2016).

Powell, Kimberly A. 2011. Framing Islam: An analysis of media coverage of terrorism since 9/11. Communication Studies 62: 90-112. [CrossRef]

Powell, Kimberly A., and Houda Abadi. 2003. Us-versus-them: Framing of Islam and Muslims after 9/11. Iowa Journal of Communication 35: 49-66.

Reese, Stephen D. 2001. Framing public life: A bridging model for media research. In Framing Public Life. Edited by Stephen D. Reese, Oscar H. Gandy Jr. and August E. Grant. Mahwah: Lawrence Erlbaum, pp. 7-31.

Reese, Stephen D., and Seth C. Lewis. 2009. Framing the war on terror: The internalization of policy in the US Press. Journalism 10: 777-97. [CrossRef]

Robles, Frances, Jason Horowitz, and Shaila Dewan. 2015. Flying the Flags of White Power. The New York Times, June 19. Available online: http:/ / search.proquest.com/usnews/docview/1689794886/30E34852CD124828PQ/ 33?accountid=27921 (accessed on 10 July 2016).

Russian Media. 2013. Russian Media Reports on Boston Bombing Suspects' Online Activity. Fox News, April 19. Available online: http:/ /www.foxnews.com/world/2013/04/19/russian-media-reports-on-boston-bombingsuspects-online-activity.html (accessed on 11 July 2016).

Ryan, Charlotte. 1991. Prime Time Activism: Media Strategies for Grassroots Organizing. Boston: South End Press.

Ryan, Missy, Adam Goldman, and Almond Phillip. 2015. San Bernardino Shooters Had Been Radicalized for 'Some Time,' FBI Says (Posted 2015-12-08 01:50:14). The Washington Post. Available online: http:/ / proxy.luther.edu/ login?url=http: / / search.proquest.com.proxy.luther.edu/docview /1744907609?accountid=27921 (accessed on 10 July 2016).

Said, Edward. 1978. Orientalism. New York: Vintage Books.

Saleem, Muniba, Sara Prot, Craig A. Anderson, and Anthony F. Lemieux. 2017. Exposure to Muslims in Media and Support for Public Policies Harming Muslims. Communication Research 44: 841-69. [CrossRef]

Schmid, Alex P. 1983. Political Terrorism: A Research Guide to Concepts, Theories, Data Bases and Literature. New Brunswick: Transaction Publishers.

Schuppe, Jon. 2015. San Bernardino shooter Tashfeen Malik's Father Condemns Attack. MSNBC, December 9. Available online: http:/ / www.msnbc.com/msnbc/san-bernardino-shooter-tashfeen-malikfather-condemns-attack (accessed on 15 July 2016).

Semati, Mehdi. 2010. Islamophobia, culture, and race in the age of empire. Cultural Studies 24: 256-75. [CrossRef]

Shah, Hemant, and Michael C. Thornton. 1994. Racial ideology in US mainstream news magazine coverage of black-latino interaction, 1980-1992. Critical Studies in Mass Communication 40: 141-61. [CrossRef]

Shahin, Saif. 2015. News Framing as Identity Performance: Religion versus Race in the American-Muslim Press. Journal of Communication Inquiry 39: 338-56. [CrossRef]

Shook, Fred. 2000. Television Field Production and Reporting. Boston: Allyn \& Bacon.

Solis, Steph, and Alison Young. 2016. Orlando Nightclub Shooting: What We Know. USA Today, June 12. Available online: http: / /www.usatoday.com/story/news/nation/2016/06/12/orlando-nightclub-shooting-whatwe-know /85786006/ (accessed on 16 July 2016).

Tuman, Joseph S. 2010. Communicating Terror: The Rhetorical Dimensions of Terrorism. New York: Sage.

Victor, Daniel, and Jack Healy. 2015. Garrett Swasey, Officer Killed in Colorado, Is Recalled for Courage and Faith. The New York Times, November 11. Available online: http:/ / www.nytimes.com/2015/11/28/us/garrettswasey-officer-killed-in-colorado-is-recalled-for-courage-and-faith.html?mtrref=query.nytimes.com (accessed on 16 July 2016).

Wagner, James. 2013. Jayson Werth on Boston Marathon: Sporting Event Being Targeted Is 'a Scary Thought'. The Washington Post. Available online: http:/ / search.proquest.com.proxy.luther.edu/docview /1327617874/ D4419F9C03DC445CPQ/50?accountid=27921 (accessed on 5 July 2016).

Wan, William. 2015. Colo. Shooting Suspect Has Long Trail of Abuse Allegations. Washington Post, December 1. Available online: http:/ / search.proquest.com/usnews/docview/1738242902/72F1774085AC43B4PQ/34? accountid=27921 (accessed on 6 August 2016).

Yan, Holly. 2015. ISIS Claims Responsibility for Texas Shooting But Offers no Proof. CNN, May 5. Available online: http:/ / www.cnn.com/2015/05/05/us/garland-texas-prophet-mohammed-contest-shooting/index.html (accessed on 5 August 2016). 
Zamost, Scott, Yasmin Khorram, Shimon Prokupecz, and Evan Perez. 2015. Chattanooga Shooting: New Details Emerge about the Gunman. CNN, July 20. Available online: http://www.cnn.com/2015/07/20/us/ tennessee-naval-reserve-shooting/index.html (accessed on 20 July 2016).

Zimmerman, Malia. 2015. Tennessee Gunman First Radicalized, Now Idolized by Internet Jihadists. Fox News, July 18. Available online: http:/ / www.foxnews.com/us/2015/07/18/tennessee-gunman-first-radicalizednow-idolized-by-internet-jihadists.html (accessed on 25 July 2016).

(c)

(C) 2018 by the author. Licensee MDPI, Basel, Switzerland. This article is an open access article distributed under the terms and conditions of the Creative Commons Attribution (CC BY) license (http:// creativecommons.org/licenses/by/4.0/). 